\title{
ANALISIS PRINSIP KESANTUNAN BERBAHASA DAN IMPLIKATUR DALAM KEGIATAN DISKUSI SISWA SMA NEGERI 1 SUMBAWA BESAR
}

\author{
Oleh \\ Sri Astiani ${ }^{1)}$ Sri Sugiarto ${ }^{2)}$ \\ ${ }^{1)}$ Fakultas Keguruan dan Ilmu Pendidikan Universitas Samawa \\ Astisriastiani2@gmail.com ${ }^{1)}$ \\ $\underline{\text { sri.sugiarto90@gmail.com }}$
}

\begin{abstract}
ABSTRAK
Penelitian ini bertujuan untuk mendeskripsikan: (1) wujud pematuhan prinsip kesantunan berbahasa, (2) wujud penyimpangan prinsip kesantunan berbahasa, (3) implikatur percakapan, dan (4) faktor penyebab penyimpangan kesantunan berbahasa. Jenis penelitian ini adalah penelitian deskriptif kualitatif. Sumber data penelitian adalah kegiatan diskusi siswa kelas $\mathrm{X}$ SMA Negeri 1 Sumbawa Besar. Teknik pengumpulan data yang digunakan adalah teknik rekam, catat, dan teknik wawancara. Teknik analisis data melalui tiga tahap yakni: reduksi data, penyajian data, dan penarikan simpulan. Hasil penelitian (1) penyimpangan kesantunan berbahasa sangat dipengaruhi oleh faktor emosi dari siswa, dan sulitnya memilih kata-kata yang tepat, (2) dalam percakapan pada kegiatan diskusi siswa kelas X SMA Negeri 1 Sumbawa Besar percakapan yang santun ditandai dengan terpenuhinya prinsip kesantunan di teori yang dituturkan oleh Leech, (3) kesantunan berbahasa kegiatan diskusi siswa dapat dikatakan cukup santun karena dari hasil penelitian tuturan yang memenuhi prinsip kesantunan berbahasa lebih banyak ditemukan dari pada yang melanggar prinsip kesantunan berbahasa, (4) implikatur percakapan pada kegiatan diskusi cukup banyak.
\end{abstract}

Kata Kunci : kesantunan berbahasa, pragmatik, skala kesantunan

\section{PENDAHULUAN}

Manusia adalah makhluk sosial. Dalam kegiatan bersosial, manusia selalu melakukan kerja sama. Kerja sama akan berjalan jika terjalin sebuah komunikasi. Wujudnya adalah terjadinya penukaran pikiran antara penutur dan lawan tutur. Pikiran-pikiran ini direalisasikan dengan bahasa. Jadi, dapat dikatakan bahwa bahasa berfungsi sebagai alat komunikasi.

Ketika berbahasa, penutur perlu memperlihatkan adanya kesantunan berbahasa ketika berkomunikasi dengan penutur lainnya. Hal tersebut bertujuan agar manusia bisa menggunakan bahasa yang santun dan tidak melakukan kesalahan dalam 
berbahasa. Kesantunan berbahasa yang dimaksud dijelaskan oleh Zamzani, dkk. (2010: 2), bahwa kesantunan (politeness) merupakan perilaku yang diekspresikan dengan cara yang baik atau beretika. Akan tetapi, pemakaian bahasa secara santun belum banyak mendapat perhatian. Oleh karena itu, sangat wajar jika sering menemukan pemakaian bahasa yang baik ragam bahasanya dan benar tata bahasanya, tetapi nilai rasa yang terkandung di dalamnya dapat menyakitkan hati pembaca atau pendengarnya. Hal ini terjadi karena pemakai bahasa belum mengetahui bahwa di dalam peristiwa berkomunikasi, selain harus mengetahui struktur kebahasaan, penutur juga harus memperhatikan aspek kesopanan. Hal demikian perlu dilakukan agar tidak menyinggung perasaan pendengar atau pembaca. Alasan lain seseorang harus membiasakan diri untuk santun dalam berbahasa karena dengan menggunakan bahasa yang santun, berarti seseorang telah menunjukkan penghargaannya kepada orang lain serta dapat menghindari terjadinya kesalahpahaman antara orang-orang yang melakukan kegiatan komunikasi tersebut.

Selain dari aspek kesantunan, setiap tuturan yang diujarkan oleh penutur menimbulkan suatu efek terhadap mitra tutur. Tuturan-tuturan yang disampaikan mempunyai makna atau maksud tertentu baik secara tersirat ataupun tersurat, secara eksplisit maupun implisit. Dengan demikian, dari tuturan-tuturan tersebut akan muncul implikatur.

Prinsip kesantunan dan implikatur merupakan salah satu bagian dari ilmu pragmatik. Pragmatik merupakan cabang ilmu linguistik yang mempelajari bahasa yang digunakan untuk berkomunikasi dalam situasi tertentu (Nadar, F.X. 2009: 2). Masalah kesantunan berbahasa yang terjadi di sekolah saat pembelajaran dapat dihindari apabila guru dan siswa menggunakan bahasa yang santun. Namun pada kenyataannya, praktik pembelajaran bahasa di sekolah lebih ditekankan pada aspek tata bahasa saja. Hal ini akan mengakibatkan praktik berbahasa siswa mencerminkan penggunaan bahasa yang tidak santun.

Tuturan-tuturan spontan yang biasa terjadi dalam kegiatan diskusi kelas merupakan ungkapan perasaan penutur. Tuturan-tuturan yang disampaikan antara tim penyaji dan peserta diskusi lebih tepat diteliti dengan menggunakan pendekatan pragmatik. Pragmatik merupakan cabang ilmu linguistik yang mempelajari maksud ujaran atau daya (force) ujaran dan fungsi 
ujaran, bukan hanya kalimat saja serta bukan hanya memandang bahasa sebagai sistem sosial dan sistem komunikasi. Selain itu, tidak semua tuturan mempunyai makna sesuai dengan kata-kata yang menyusunnya, terkadang ada maksud yang tersembunyi di belakangnya. Apa yang mungkin diartikan, disiratkan, atau dimaksudkan oleh penutur yang berbeda dari apa yang sebenarnya dikatakan oleh penutur di dalam suatu percakapan disebut implikatur yang merupakan salah satu bagian dari ilmu pragmatik.

Sebagai contoh, pada saat kegiatan diskusi berlangsung, seorang siswa dari kelompok penyaji membacakan materi diskusi dengan suara yang pelan sehingga peserta diskusi yang berada di bagian belakang tidak dapat mendengar dengan jelas suara penyaji tersebut. Lalu seorang siswa yang duduk di bagian belakang menyuruh siswa penyaji tersebut untuk mengencangkan volume suaranya. "Hey, keraskan suaramu!" teriak siswa itu. Dari contoh tersebut, sudah jelas bahwa siswa tersebut berbahasa tak santun karena dalam berbahasa lisan, seseorang dinilai tidak santun jika menggunakan intonasi yang keras. Selain itu, menurut Abdul Chaer (2010:57), memerintah dengan kalimat berita atau kalimat tanya dipandang lebih santun dibandingkan dengan kalimat perintah (imperatif). Kenyataan seperti ini juga dapat ditemui pada siswa SMA Negeri 1 Sumbawa Besar.

Berdasarkan pengamatan awal terhadap kegiatan diskusi yang dilakukan siswa, dapat dinyatakan bahwa sebagian siswa tidak menggunakan bahasa yang mencerminkan prinsip kesantunan. Hal ini terjadi saat berdiskusi, antara kelompok penyanji dan penanggap tidak saling menghargai satu sama lain. Bukti ini dapat terlihat saat beberapa di antaranya yang tidak menghargai pendapat orang lain, masih salah dalam pemilihan kata, misalnya, tuturan yang terkadang berupa sindiran atau bantahan yang dapat menyinggung perasaan orang lain.

Berdasarkan uraian masalah di atas, perlu adanya kajian yang berkaitan dengan kesantunan berbahasa dan implikatur percakapan pada siswa sebagai upaya mengindahkan norma kesopanan dalam proses pembelajaran. Oleh karena itu, peneliti akan menganalisis tentang prisipprinsip kesantunan berbahasa dan implikatur pada kegiatan diskusi, serta penerapan prinsip kesantunan berbahasa dalam pembelajaran Bahasa Indonesia khususnya 
pada keterampilan berbicara dengan metode diskusi.

Istilah pragmatik didefinisikan oleh Richards (Edi Tri Sulistyo, 2013: 2) mengatakan bahwa pragmatik adalah kajian tentang penggunaan bahasa di dalam komunikasi, terutama hubungan di antara kalimat dan konteks yang disertai situasi penggunaan kalimat itu. Sementara itu, Nadar (2009: 2) mendefinisikan pragmatik sebagai cabang linguistik yang mempelajari bahasa yang digunakan untuk berkomunikasi dalam situasi tertentu.

Semantik mempelajari makna secara internal, sedangkan pragmatik mempelajari makna secara eksternal. Telaah semantik adalah makna yang bebas konteks, sedangkan makna yang dikaji oleh pragmatik, yaitu makna yang terikat oleh konteks. Hal ini tentu berkaitan dengan siapa yang berbicara, dengan bahasa apa berbicara, kapan, dan dengan tujuan apa berbicara. Pengajaran pragmatik pada murid dapat berupa bagaimana ia menyatakan kesanggupan atau ketidaksanggupan, bagaimana menyatakan permintaan maaf, menyatakan setuju atau tidak setuju terhadap sesuatu, bagaimana memperkenalkan diri, bagaimana cara memuji, melaporkan, dan sebagainya.
Pragmatik adalah studi tentang makna yang disampaikan oleh penutur (atau penulis) dan ditafsirkan oleh pendengar (atau pembaca). Sebagai akibatnya, studi ini lebih banyak berhubungan dengan analisis tentang apa yang dimaksudkan orang dengan tuturan-tuturannya daripada dengan makna terpisah dari kata atau frasa yang digunakan dalam tuturan itu sendiri. Pragmatik adalah studi tentang maksud penutur.

\section{METODE PENELITIAN}

Untuk mengungkapkan bentuk kesantunan berbehasa serta implikatur tindak tutur kegiatan siswa dalam kegiatan diskusi, peneliian ini digunakan jenis penelitian kualitatif. Tohirin (2013: mengemukakan empat jenis penelitian kualitatif, yaitu studi kasus, ground theory, etnografi, dan analisis wacana. Pendekatan yang digunakan dalam penelitian ini mengunakan pendekatan analisis wacana pragmatig.Pada penelitian ini, peneliti ingin mengetahui secara mendalam dan terperinci mengenai pematuhan dan penyimpangan prinsip kesantunan berbahasa, serta penyebab terjadinya penyimpangan tersebut pada kegiatan diskusi siswa.

Penelitian mengenai analisis prinsip kesantunan berbahasa ini akan diadakan di SMA Negeri 1 Sumbawa Besar. SMA 
Negeri 1 Sumbawa Besar dipilih sebagai tempat diadakan penelitian karena peneliti telah melakukan observasi terlebih dahulu dan mendapatkan hasil bahwa masih banyak siswa yang tidak mematuhi prinsip kesantunan berbahasa. Data dalam penelitian ini berupa teks tuturan percakapan yang mengandung prinsip kesantunan berbahasa. Data tersebut meliputi pematuhan terhadap prinsip kesantunan berbahasa, penyimpangan terhadap prinsip kesantunan berbahasa, dan faktor penyebab terjadinya penyimpangan tersebut pada kegiatan diskusi siswa kelas X SMA Negeri 1 Sumbawa Besar. Pematuhan dan penyimpangan prinsip kesantunan berbahasa dapat diidentifikasi dengan melihat video rekaman kegiatan diskusi siswa. Sedangkan faktor penyebab terjadinya kesalahan tersebut dapat diketahui dari hasil wawancara yang dilakukan kepada guru dan siswa itu sendiri.

Teknik pengumpulan data pada penelitian ini ialah observasi terhadap kegiatan diskusi dan wawancara terhadap guru dan siswa. Teknik observasi merupakan teknik pengumpulan data yang dilakukan dengan jalan mengamati fenomenafenomena yang terjadi di lokasi penelitian. Melalui teknik ini diharapkan akan mendapatkan gambaran yang lebih lengkap dan menyeluruh mengenai obyek yang diamati. Observasi dilakukan untuk mengamati pematuhan dan penyimpangan prinsip kesantunan berbahasa pada kegiatan diskusi siswa kelas X SMA Negeri 1 Sumbawa Besar.

Selanjutnya, sambil mengobservasi, peneliti merekam proses kegiatan diskusi yang dilakukan oleh siswa kelas X SMA Negeri 1 Sumbawa Besar, setelah itu menyimaknya untuk mengetahui pematuhan dan penyimpangan prinsip kesantunan, kemudian mencatat hasilnya.

Teknik yang berikutnya yaitu teknik wawancara. Wawancara dilakukan oleh peneliti terhadap guru mata pelajaran bahasa Indonesia. Wawancara tersebut digunakan untuk memperoleh data berupa faktor penyebab terjadinya penyimpangan prinsip kesantunan berbahasa pada kegiatan diskusi siswa kelas X SMA Negeri 1 Sumbawa Besar. Jenis wawancara yang akan dilakukan, yaitu wawancara terstrukutur agar data yang diperoleh dalam penelitian lebih mendalam.

Teknik analisis data yang digunakan dalam penelitian ini adalah analisis model interaktif (Interactive Model of Analysis). Menurut Miles dan Huberman 
(2009: 15) teknik analisis data seperti ini dilakukan dengan empat alur kegiatan yang terjadi secara bersamaan, yaitu pengumpulan data, reduksi data (data reduction), penyajian data (data display), dan conclusion drawing/verification.

\section{HASIL PENELITIAN DAN}

\section{PEMBAHASAN}

Hasil dari penelitian Analisis

Prinsip Kesantunan Bebahasa dan Implikatur dalam Kegiatan Diskusi Siswa SMA Negeri 1 Sumbawa Besar ini berupa deskripsi pematuhan dan penyimpangan prinsip kesantunan berbahasa serta implikatur percakapan yang terjadi dalam kegiatan diskusi siswa kelas X MIA 1 dan X MIA 2. Berdasarkan data yang diperoleh dalam penelitian, ditemukan pematuhan dan penyimpangan prinsip kesantunan berbahasa, serta implikatur percakapan. Keseluruhan data yang terkumpul berdasarkan jumlah kartu data yakni 86 data tuturan. Kartu data yang berupa pematuhan prinsip kesantunan berbahasa berjumlah 53 data, penyimpangan prinsip kesantunan berbahasa berjumlah tujuh data, dan implikatur percakapan berjumlah 24 data.

\section{Pematuhan Prinsip Kesantunan dalam Kegiatan Diskusi Siswa kelas X SMA Negeri 1 Sumbawa Besar}

Pematuhan prinsip kesantunan berbahasa yang ditemukan dalam kegiatan diskusi siswa SMA Negeri 1 Sumbawa Besar berjumlah 53 tuturan. Pematuhan tersebut meliputi empat dari enam maksim pada teori Leech, di antaranya ialah pematuhan maksim kebijaksanaan, penerimaan, kemurahan, dan kesimpatian. Dari 53 tuturan pematuhan prinsip kesantunan berbahasa, maksim yang paling banyak dipatuhi adalah maksim kebijaksanaan sebanyak 22 tuturan.

\section{Penyimpangan Prinsip Kesantunan dalam Kegiatan Diskusi Siswa kelas X SMA Negeri 1 Sumbawa Besar}

Penyimpangan prinsip kesantunan berbahasa yang ditemukan dalam kegiatan diskusi siswa SMA Negeri 1 Sumbawa Besar berjumlah tujuh tuturan. Penyimpangan tersebut meliputi tiga dari enam maksim pada teori Leech, di antaranya ialah penyimpangan maksim kebijaksanaan, penerimaan, dan kemurahan. Dari tujuh tuturan penyimpangan prinsip kesantunan berbahasa, maksim yang paling banyak dilanggar adalah maksim kebijaksanaan sebanyak empat tuturan. 
Implikatur Percakapan dalam Kegiatan Diskusi Siswa kelas X SMA Negeri 1 Sumbawa Besar

Hasil penelitian, jumlah implikatur percakapan pada kegiatan diskusi siswa SMA Negeri 1 Sumbawa Besar berjumlah 24 data. Implikatur tersebut meliputi implikatur menolak, menyindir, tidak setuju, menyatakan pemberitahuan, dan menyuruh.

\section{Wujud Pematuhan Kesantunan dalam Kegiatan Diskusi Siswa kelas X SMA Negeri 1 Sumbawa Besar}

a. Pematuhan Maksim Kebijaksanaan

Maksim kebijaksanaan dalam prinsip kesantunan adalah bahwa setiap peserta penuturan harus meminimalkan kerugian orang lain, atau memaksimalkan keuntungan bagi orang lain (Abdul Chaer, 2010: 56). Rahardi (2005: 60) mengungkapkan gagasan dasar dalam maksim kebijaksanaan dalam prinsip kesantunan adalah bahwa para peserta pertuturan hendaknya berpegang pada prinsip untuk selalu mengurangi keuntungan dirinya sendiri dan memaksimalkan keuntungan pihak lain dalam kegiatan bertutur. Orang bertutur yang berpegang dan melaksanakan maksim kebijaksanaan akan dapat dikatakan sebagai orang santun. Maksim kebijaksanaan terdiri dari lima indikator, yaitu (a) menggunakan diksi yang

halus dalam bertanya, mengemukakan pendapat, menyanggah jawaban peserta diskusi lain (misalnya menggunakan kata maaf, terima kasih, berkenan, mohon, tolong, beliau, bapak/ibu, silahkan), (b) menegur peserta diskusi lainnya dengan diksi yang halus, (c) memberikan banyak keuntungan untuk orang lain (tidak memaksakan pendapatnya pada orang lain), (d) tidak menyindir peserta diskusi atau kelompok lain dalam berpendapat atau bertanya, (e) menolak/membantah pendapat peserta diskusi lain dengan kata "maaf". Pematuhan maksim kebijaksanaan pada penelitian ini terdapat 22 data. Data yang merupakan pematuhan maksim kearifan dilihat pada contoh percakapan berikut:

Moderator : Sekian presentasi dari kami, apakah ada yang ingin menanggapi dari apa yang telah kami sampaikan, kami akan memilih dua penanggap saja. Yang pertama dari yang duduk di depan.

$\begin{array}{rll}\text { Penanggap : } & \text { Baik terima kasih, } \\ & \text { perkenalkan saya Nana. }\end{array}$ (DS.01.02)

Terjadi peristiwa tutur yang
dilakukan oleh moderator dan peserta
diskusi. Tuturan disampaikan dengan
intonasi yang sedang dan dalam suasana

Terjadi peristiwa tutur yang 78 
santai, namun formal. Moderator bermaksud memberikan kesempatan kepada peserta diskusi untuk bertanya. Para peserta mulai bertanya dan memberikan tanggapan mereka.

Dapat dilihat data (DS.01.02) pada tuturan yang dituturkan oleh penanggap "Baik terima kasih, perkenalkan saya Nana". Kata "terima kasih" merupakan ciri yang menunjukkan adanya unsur maksim kebijaksanaan karena kata tersebut memilik makna menghormati, serta member penghargaan kepada orang lain.

Contoh data lain yang menunjukkan pematuhan maksim kebijaksanaan dapat dilihat pada percakapan berikut.

$\begin{array}{ll}\text { Penyaji } & \text { Terima kasih, mungkin } \\ & \text { kami akan menanggapi } \\ & \text { pendapat Anda. PT yang } \\ & \text { berasal dari luar negeri itu } \\ & \text { tetap harus mengikuti } \\ \text { peraturan. } & \\ \text { Penanggap : } & \text { Kalau dia menggunakan } \\ & \text { bahasa Indonesia, berarti } \\ & \text { identitasnya akan hilang. } \\ \text { Moderator }: & \text { Saudari Patricia tolong } \\ & \text { jangan } \\ & \text { DS.01.48 memotong. }\end{array}$

Dapat dilihat data (DS.01.48) pada tuturan yang dituturkan oleh moderator "Saudari Patricia tolong jangan memotong". Moderator berbicara dengan santun ketika menegur peserta diskusi yang memotong pembicaraan tim penyaji. Tuturan moderator tersebut mematuhi prinsip kesantunan dengan maksim kebijaksanaan pada indikator kedua karena moderator telah menegur Patricia secara halus dan menggunakan kata "tolong”.

\section{b. Pematuhan Maksim Penerimaan}

Rahardi (2005: 61) mengatakan bahwa dengan maksim penerimaan/kedermawanan atau maksim kemurahan hati, para peserta pertuturan diharapkan dapat menghormati orang lain. Penghormatan terhadap orang lain akan terjadi apabila orang dapat mengurangi keuntungan bagi dirinya sendiri dan memaksimalkan keuntungan bagi pihak lain. Maksim penerimaan terdiri dari tiga indikator, yaitu (a) memberikan kesempatan pada orang lain atau kelompok lain untuk berpendapat, bertanya, memberikan kritikan, (b) memberikan perintah dengan kalimat pertanyaan atau kalimat berita, (c) menolak pendapat orang lain dengan kalimat pertanyaan. Pematuhan maksim penerimaan pada penelitian ini terdapat 12 data. Data yang merupakan pematuhan maksim penerimaan dilihat pada contoh percakapan berikut. 


\begin{abstract}
Penyaji : Sekian presentasi dari kami, apakah ada yang ingin menanggapi dari apa yang telah kami sampaikan, kami akan memilih dua penanggap saja. Yang pertama dari yang duduk di depan.

Penanggap : Baik terima kasih, perkenalkan saya Nana.
\end{abstract}

(DS 01.01)

Terjadi peristiwa tutur yang dilakukan oleh moderator dan peserta diskusi. Ketika tim penyaji selesai membacakan materinya, moderator mempersilahkan peserta diskusi untuk menanggapi materi yang telah dibacakan oleh penyaji.

Dapat dilihat data (DS 01.01) pada tuturan yang dituturkan oleh moderator "apakah ada yang ingin menanggapi dari apa yang telah kami sampaikan". Kalimat tersebut termasuk pertanyaan yang bermaksud memberikan kesempatan untuk menanggapi. Pemberian kesempatan ini termasuk pada indikator maksim kedermawanan. Moderator berbicara dengan santun pada saat menyuruh peserta untuk menanggapi materi yang telah dipresentasikan oleh tim penyaji.

Contoh percakapan lain yang merupakan pematuhan maksim penerimaan ialah sebagai berikut.
Moderator : Selanjutnya, silahkan Dino.

Dino : Pendapat saya, saya tidak setuju dengan bahasa gaul di Facebook. Kenapa? Karena, buat apa kita sekolah dari TK sampai SMA atau pergguruan tinggi tetapi tidak menggunakan bahasa Indonesia yang baik dan benar dan malah menggunakan bahasa gaul? Nah, kalau kita sering menggunakan bahasa gaul, bisa saja ke depannya bahasa Indonesia akan kalah dan malah akan punah. Ya, sekian dari saya. (DS:01.60)

Dapat dilihat data 01.60 pada tuturan yang dituturkan oleh penanggap "buat apa kita sekolah dari TK sampai SMA atau pergguruan tinggi tetapi tidak menggunakan bahasa Indonesia yang baik dan benar dan malah menggunakan bahasa gaul?", penanggap yang bernama Dino berbicara dengan santun ketika menolak/membantah pendapat penyaji. Tuturan tersebut mematuhi prinsip kesantunan dengan maksim penerimaan karena Dino menolak/membantah pendapat penyaji dengan kalimat pertanyaan.

\section{c. Pematuhan Maksim Kemurahan \\ Nadar (2009: 30) memberikan} contoh tuturan ekspresif yakni mengucapkan selamat, mengucapkan terima kasih, memuji, 
dan mengungkapkan bela sungkawa. Dalam maksim ini menuntut setiap peserta pertuturan untuk memaksimalkan rasa hormat kepada orang lain, dan meminimalkan rasa tidak hormat kepada orang lain. Maksim kemurahan terdiri dari enam indikator, yaitu (a) mampu menghargai pendapat orang lain, (b) memberikan kritik yang membangun, tidak menjatuhkan orang lain, (c) memberikan pujian yang jujur pada pendapat orang lain, (d) mengucapkan "terima kasih" ketika mendapat saran/kritikan dari orang lain, (e) tidak mempermalukan lawan tutur ketika sedang berdiskusi di muka umum, (f) menggunakan tuturan tidak langsung dan tuturan panjang ketika berpendapat, menolak dan mengkritik pendapat orang lain. Pematuhan maksim kemurahan pada penelitian ini terdapat 17 data. Data yang merupakan pematuhan maksim kemurahan dilihat pada contoh percakapan berikut.

$\begin{aligned} \text { Penanggap : } & \text { Baik terima kasih,.... } \\ \text { Moderator : } & \text { Baik, terima kasih atas } \\ & \text { tanggapan yang Anda } \\ & \text { berikan, kami akan } \\ & \text { menanggapi apa yang telah } \\ & \text { disampaikan oleh saudari } \\ & \text { Nana. (DS:01.03 }\end{aligned}$

Dapat dilihat data (DS:01.03) pada tuturan yang dituturkan oleh penanggap, penanggap telah mematuhi maksim kemurahan/penghargaan karena telah diberikan kesempatan untuk menanggapi, karena dalam maksim ini menuntut setiap peserta pertuturan untuk memaksimalkan rasa hormat kepada orang lain, dan meminimalkan rasa tidak hormat kepada orang lain.

\section{d. Pematuhan Maksim Kesimpatian}

Sikap antipati terhadap salah seorang peserta tutur akan dianggap sebagai tindakan tidak santun. Orang yang bersikap antipati terhadap orang lain, apalagi sampai bersikap sinis terhadap pihak lain, akan dianggap sebagai orang yang tidak tahu sopan santun di dalam masyarakat (Rahardi, 2005: 65). Bila lawan tutur mendapatkan kesusahan, atau musibah, penutur layak turut berduka, atau mengutarakan ucapan bela sungkawa sebagai tanda kesimpatian. Maksim kesimpatian terdiri dari dua indikator, yaitu (a) memberikan dukungan yang tulus pada pendapat orang lain jika benar, (b) memberikan rasa simpati yang tulus pada orang lain yang pendapatnya salah. Pematuhan maksim kesimpatian pada penelitian ini terdapat dua data. Data yang merupakan pematuhan maksim kesederhanaan dilihat pada contoh percakapan berikut.

Moderator : Jadi bukan berarti menghilangkan identitas, 
tetapi hanya mengubah namanya untuk berpartisipasi dengan daerah yang ditempati....

$\begin{array}{rlr}\text { Penanggap : } & \text { Terima kasih. Saya } \\ & \text { mendukung mosi kali ini } \\ & \text { bahwasanya papan nama } \\ & \text { usahar harus } \\ & \text { menggunakan bahasa } \\ & \text { Indonesia....(DS: 01.05) }\end{array}$

Dapat dilihat data 01.50 pada tuturan yang dituturkan oleh penanggap, penanggap telah membantu tim penyaji dengan cara memberi dukungan terhadap pendapat dari kelompok penyaji dengan tulus. Adapun pematuhan prinsip kesantunan dalam tuturan kegiatan diskusi kelas X SMA Negeri 1 Sumbawa Besar, secara lebih lengkap dapat dilihat pada tabel berikut.

Tabel 1

Pematuhan prinsip kesantunan dalam kegiatan diskusi

\begin{tabular}{|c|c|c|}
\hline No & $\begin{array}{c}\text { Pematuhan Prinsip } \\
\text { Kesantunan }\end{array}$ & $\begin{array}{c}\text { Nomor } \\
\text { Data }\end{array}$ \\
\hline 1. & \multicolumn{2}{|c|}{ Indokator Maksim Kebijaksanaan } \\
\hline & $\begin{array}{l}\text { a. Menggunakan diksi yang } \\
\text { halus dalam bertanya, } \\
\text { mengemukakan pendapat, } \\
\text { menyanggah jawaban } \\
\text { peserta diskusi lain } \\
\text { (misalnya menggunakan } \\
\text { kata maaf, terima kasih, } \\
\text { berkenan, mohon, tolong, } \\
\text { beliau, bapak/ibu, } \\
\text { silahkan), }\end{array}$ & $\begin{array}{l}02,10, \\
12,15, \\
17,20, \\
21,24, \\
30,33, \\
34,36, \\
37,41, \\
42,44, \\
45,48, \\
54,56\end{array}$ \\
\hline & $\begin{array}{ll}\text { b. } & \text { Menegur peserta diskusi } \\
\text { lainnya dengan diksi yang } \\
\text { halus, }\end{array}$ & 48 \\
\hline & c. Memberikan banyak & 61 \\
\hline
\end{tabular}

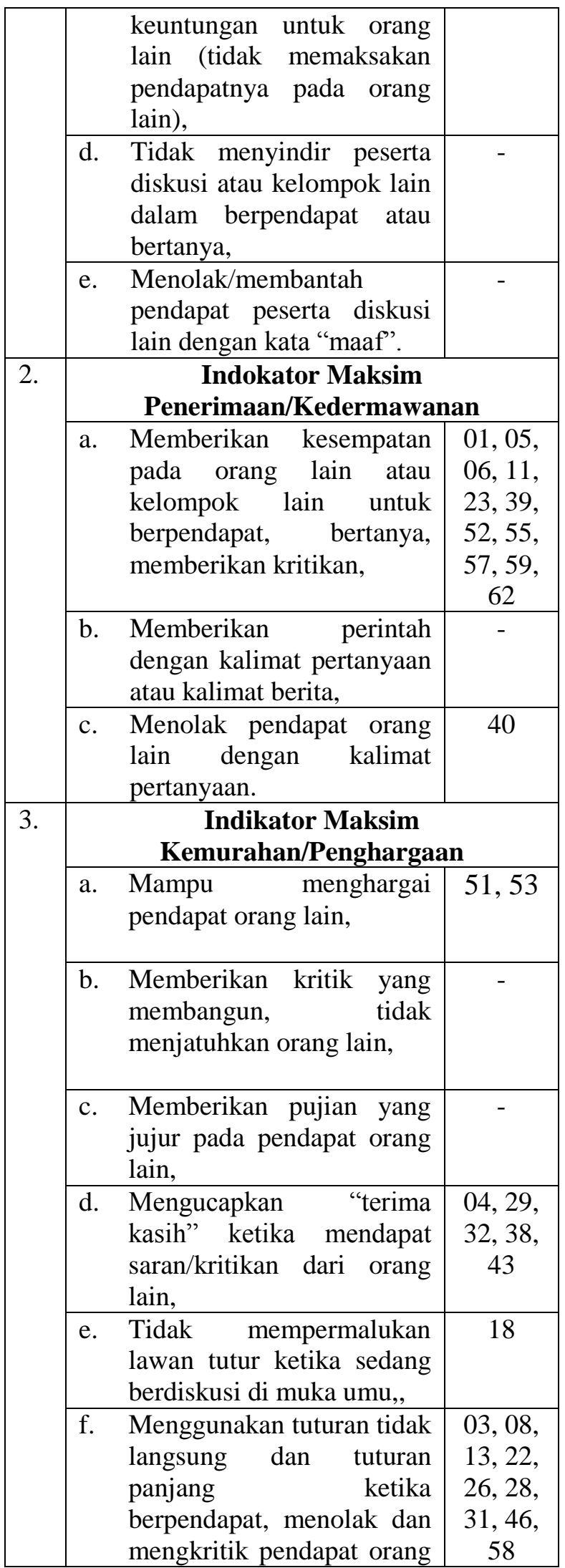




\begin{tabular}{|c|c|c|c|}
\hline & & lain, & \\
\hline \multirow[t]{3}{*}{4.} & \multicolumn{3}{|c|}{$\begin{array}{c}\text { Indikator Maksim Kerendahan } \\
\text { Hati/Kesederhanaan }\end{array}$} \\
\hline & & $\begin{array}{l}\text { Selalu berprasangka baik } \\
\text { pada peserta lain, }\end{array}$ & - \\
\hline & b. & $\begin{array}{l}\text { Tidak } \\
\text { menonjolkan/memamerkan } \\
\text { kelebihan dirinya sendiri } \\
\text { pada orang lain. }\end{array}$ & - \\
\hline \multirow[t]{4}{*}{5.} & \multicolumn{3}{|c|}{$\begin{array}{c}\text { Indikator Maksim } \\
\text { Kecocokan/Pemufakatan }\end{array}$} \\
\hline & & $\begin{array}{l}\text { Mau mendukung pendapat } \\
\text { yang benar, meskipun } \\
\text { pendapatnya sebelumnya } \\
\text { salah, }\end{array}$ & - \\
\hline & & $\begin{array}{l}\text { Berbicara sesuai situasi/ } \\
\text { pokok permasalahan yang } \\
\text { sedang dibicarakan, }\end{array}$ & - \\
\hline & & $\begin{array}{ll}\text { Mau menerima } & \text { hasil } \\
\text { diskusi. } & \end{array}$ & - \\
\hline \multirow[t]{3}{*}{6.} & \multicolumn{3}{|c|}{ Indikator Maksim Kesimpatian } \\
\hline & & $\begin{array}{l}\text { Memberikan dukungan } \\
\text { yang tulus pada pendapat } \\
\text { orang lain jika benar, }\end{array}$ & 07,50 \\
\hline & & $\begin{array}{l}\text { Memberikan rasa simpati } \\
\text { yang tulus pada orang lain } \\
\text { yang pendapatnya salah. }\end{array}$ & - \\
\hline
\end{tabular}

\section{Wujud Penyimpangan Kesantunan dalam Kegiatan Diskusi Siswa kelas X SMA Negeri 1 Sumbawa Besar}

\section{a. Penyimpangan Kebijaksanaan}

Maksim

Maksim Kebijaksanaan terdiri dari lima indikator, yaitu (a) menggunakan diksi yang kasar dalam bertanya, mengemukakan pendapat, menyanggah jawaban peserta diskusi lain (misalnya tidak menggunakan kata maaf, terima kasih, berkenan, mohon, tolong, beliau, bapak/ibu), silahkan, (b) menegur peserta diskusi lainnya dengan diksi yang kasar, (c) memaksakan pendapatnya pada orang lain, (d) menyindir peserta diskusi atau kelompok lain dalam berpendapat atau bertanya, menolak/membantah pendapat peserta diskusi lain tidak dengan kata "maaf". Data yang merupakan pelanggaran maksim kebijaksanaan dapat dilihat pada contoh percakapan berikut.
Penyaji : Tadi saudara tidak setuju dengan kelompok kami....

Penanggap : Interupsi! Saya tidak setuju dengan pendapat Anda. Anda bilang tadi novel seperti cinta-cinta. (DS:01.27)

Pada percakapan 01.27 terdapat penyimpangan maksim kebijaksanaan karena peserta diskusi/penanggap tersebut menolak pendapat yang diberikan oleh penyaji tanpa adanya kata "maaf". Penyimpangan maksim kebijaksanaan terjadi apabila menolak/membantah pendapat peserta diskusi lain tidak dengan kata "maaf".

\section{b. Penyimpangan Maksim Penerimaan}

Maksim penerimaan terdiri dari tiga indikator, yaitu (a) tidak memberikan kesempatan pada orang lain atau kelompok lain untuk berpendapat, bertanya, memberikan kritika, (b) memberikan perintah dengan kalimat perintah, (c) 
menolak pendapat orang lain tidak dengan kalimat pertanyaan. Data yang merupakan pelanggaran maksim penerimaan dapat dilihat pada contoh percakapan berikut.

$\begin{array}{lll}\text { Penyaji } & : \text { Baiklah saya akan } \\ & \text { menambahkan sedikit.... } \\ \text { Moderator }: & \text { Tidak. Jadi, Fulday School itu } \\ & \text { tidak dapat menghindarkan } \\ & \text { siswa dari pengaruh buruk.. } \\ & (\text { DS:01.09) }\end{array}$

Terjadi peristiwa tutur yang dilakukan oleh moderator dan peserta diskusi. Moderator tidak memberikan kesempatan pada peserta diskusi untuk berpendapat. Pada tuuran 01.09, moderator berkata "Tidak." Ketika banyak peserta diskusi ingin menanggapi pendapat dari tim penyaji.

\section{c. Penyimpangan Maksim Kemurahan}

enam indikator, yaitu (a) tidak mau menghargai pendapat orang lain, (b) memberikan kritik yang menjatuhkan orang lain, (c) berbicara yang menyakiti hati orang lain, (d) tidak mengucapkan "terima kasih" ketika mendapat saran/kritikan dari orang lain, (e) mempermalukan lawan tutur ketika sedang berdiskusi di muka umum, (f) menggunakan tuturan langsung ketika berpendapat, menolak dan mengkritik. Data yang merupakan pelanggaran maksim kemurahan dapat dilihat pada contoh percakapan berikut.

Terjadi peristiwa tutur antara moderator dan peserta diskusi. Saat peserta diskusi selesai memberikan maaf, moderator tidak menghargainya.

$\begin{array}{lll}\text { Penanggap : } & \text { Terimakasih atas } \\ & \text { kesampatan yang diberikan } \\ & \text { kepada saya, saya di sini } \\ & \text { ingin bertanya dan } \\ & \text { menanggapi... } \\ \text { Moderator : } & \text { Kita lanjutkan saja, nanti } \\ & \text { ditanggapi oleh tim } \\ & \text { penyaji ya. Lanjut yang } \\ & \text { berikutnya, Dino tadi } \\ & \text { angkat } \\ & \text { disilahkan. (DS:01.14) }\end{array}$

Pada data 01.14, penyimpangan maksim kemurahan khususnya pada indikator keempat, karena tidak mengucapkan "terima kasih" ketika mendapat saran/kritikan dari orang lain. Ketika peserta diskusi selesai memberikan pendapatnya, moderator langsung membuka sesi pertanyaan berikutnya tanpa mengucapkan "terima kasih" terlebih dahulu kepada peserta diskusi yang telah berpendapat. Adapun penyimpangan prinsip kesantunan dalam tuturan kegiatan diskusi kelas X SMA Negeri 1 Sumbawa Besar, secara lebih lengkap dapat dilihat pada table berikut. 
Tabel 2

Penyimpangan prinsip kesantunan dalam kegiatan diskusi siswa

\begin{tabular}{|c|c|c|}
\hline No & $\begin{array}{c}\text { Penyimpangan Prinsip } \\
\text { Kesantunan }\end{array}$ & $\begin{array}{c}\text { Nomor } \\
\text { Data }\end{array}$ \\
\hline
\end{tabular}

1. Indikator Maksim Kebijaksanaan

a. Menggunakan diksi yang 27,47 halus dalam bertanya, mengemukakan pendapat, menyanggah jawaban peserta diskusi lain (misalnya menggunakan kata maaf, terima kasih, berkenan, mohon, tolong, beliau, bapak/ibu, silahkan),

b. Menegur peserta diskusi lainnya dengan diksi yang halus,

c. Memberikan banyak 25 keuntungan untuk orang lain (tidak memaksakan pendapatnya pada orang lain),

d. Tidak menyindir peserta diskusi atau kelompok lain dalam berpendapat atau bertanya,

e. Menolak/membantah 49 pendapat peserta diskusi lain dengan kata "maaf".

\section{$2 . \quad$ Indikator Maksim Penerimaan/Kedermawanan}

a. Memberikan kesempatan 09 pada orang lain atau kelompok lain untuk berpendapat, bertanya, memberikan kritikan,

b. Memberikan perintah dengan kalimat pertanyaan atau kalimat berita,

c. Menolak pendapat orang lain dengan kalimat pertanyaan.

\section{$3 . \quad$ Indikator Maksim} Kemurahan/Penghargaan

a. Mampu menghargai pendapat orang lain,

b. Memberikan kritik yang

\begin{tabular}{|c|c|c|}
\hline & $\begin{array}{l}\text { membangun, tidak } \\
\text { menjatuhkan orang lain, }\end{array}$ & \\
\hline & $\begin{array}{l}\text { c. Memberikan pujian yang } \\
\text { jujur pada pendapat orang } \\
\text { lain, }\end{array}$ & \\
\hline & $\begin{array}{ll}\text { d. } & \text { Mengucapkan "terima } \\
\text { kasih" ketika mendapat } \\
\text { saran/kritikan dari orang } \\
\text { lain, }\end{array}$ & 14 \\
\hline & $\begin{array}{l}\text { e. Tidak mempermalukan } \\
\text { lawan tutur ketika sedang } \\
\text { berdiskusi di muka umu, }\end{array}$ & - \\
\hline & $\begin{array}{llr}\text { f. } & \text { Menggunakan tuturan } \\
\text { tidak langsung dan tuturan } \\
\text { panjang ketika } \\
\text { berpendapat, menolak dan } \\
\text { mengkritik pendapat orang } \\
\text { lain, }\end{array}$ & - \\
\hline 4. & $\begin{array}{c}\text { Indikator Maksim Kerenda } \\
\text { Hati/Kesederhanaan }\end{array}$ & \\
\hline & $\begin{array}{l}\text { a. Selalu berprasangka baik } \\
\text { pada peserta lain, }\end{array}$ & - \\
\hline & $\begin{array}{ll}\text { b. } & \text { Tidak } \\
\text { menonjolkan/memamerkan } \\
\text { kelebihan dirinya sendiri } \\
\text { pada orang lain. }\end{array}$ & - \\
\hline 5. & $\begin{array}{c}\text { Indikator Maksim } \\
\text { Kecocokan/Pemufakata }\end{array}$ & \\
\hline & $\begin{array}{l}\text { a. Mau mendukung pendapat } \\
\text { yang benar, meskipun } \\
\text { pendapatnya sebelumnya } \\
\text { salah, }\end{array}$ & - \\
\hline & $\begin{array}{l}\text { b. Berbicara sesuai situasi/ } \\
\text { pokok permasalahan yang } \\
\text { sedang dibicarakan, } \\
\end{array}$ & - \\
\hline & $\begin{array}{lll}\text { c. } & \begin{array}{l}\text { Mau menerima hasil } \\
\text { diskusi. }\end{array}\end{array}$ & - \\
\hline 6. & Indikator Maksim Kesimpa & \\
\hline & $\begin{array}{l}\text { a. Memberikan dukungan } \\
\text { yang tulus pada pendapat } \\
\text { orang lain jika benar, }\end{array}$ & - \\
\hline & $\begin{array}{l}\text { b. Memberikan rasa simpati } \\
\text { yang tulus pada orang lain } \\
\text { yang pendapatnya salah. }\end{array}$ & - \\
\hline
\end{tabular}

Implikatur Percakapan dalam Kegiatan Diskusi Siswa Kelas X SMA Negeri 1 Sumbawa Besar 
Pelanggaran dan pematuhan terhadap prinsip kesantunan menunjukkan adanya sebuah implikatur yang terkandung dalam tuturan tersebut. Implikatur adalah makna lain yang terdapat dalam suatu tuturan. Makna ini biasanya tersirat, jadi penutur mengungkapkan maksud dari tuturannya secara tidak langsung, sehingga petutur harus menginterpretasikan sendiri maksud dari penutur.

Dalam kegiatan diskusi siswa kelas X SMA Negeri 1 Sumbawa Besar, akan dijelaskan implikatur berdasarkan fungsinya, yaitu implikatur menolak, menyindir, tidak setuju, menyatakan pemberitahuan, mengejek, menyombongkan diri, dan menyuruh. Namun, dalam penelitian ini hanya ada lima implikatur saja yang akan dijelaskan, yaitu meliputi menolak, menyindir, tidak setuju, menyatakan pemberitahuan, dan menyuruh.

\section{a. Implikatur Menyindir}

Implikatur menyindir adalah apa yang mungkin diartikan, disiratkan, atau dimaksudkan oleh penutur mempunyai maksud menyindir orang lain. Data yang menunjukkan implikatur 'menyindir' dapat dilihat pada percakapan berikut.

Moderator : Selanjutnya, silahkan Dino. Penanggap : ...Karena, buat apa kita sekolah dari TK sampai
SMA atau pergguruan tinggi tetapi tidak menggunakan bahasa Indonesia yang baik dan benar dan malah menggunakan bahasa gaul?.... (DS:01.60)

Dalam tuturan "Karena, buat apa kita sekolah dari TK sampai SMA atau pergguruan tinggi tetapi tidak menggunakan bahasa Indonesia yang baik dan benar dan malah menggunakan bahasa gaul?", tuturan tersebut bermaksud menyindir. Isi tersirat dari tuturan tersebut bahwa orang yang berpendidikan semestinya menjaga tutur katanya dengan menggunakan bahasa yang baik. Jika ada orang berpendidikan tinggi menggunakan bahasa gaul, berarti ia tidak menggunakan ilmu dan pengetahuan yang dia dapat di bangku pendidikan.

\section{b. Implikatur Tidak Setuju}

Implikatur menolak adalah tuturan yang mempunyai maksud lain tidak menerima (memberi, mengabulkan, meluruskan) keinginan mitra tuturnya. Data yang menunjukkan implikatur menolak dapat dilihat pada percakapan di bawah ini.

Moderator : Baik, terimakasih atas tanggapan yang Anda berikan, kami akan menanggapi apa yang telah disampaikan oleh saudari Nana. 
Penanggap : $\ldots \quad$ Nah, bagaimana dengan siswa yang membutuhkan istirahat, apa ia tidak jenuh? Ketika ia baru selesai belajar, selanjutnya ia akan mengikuti kegiatan ekstrakulikuler, apakah tidak ada istirahatnya?.... (DS:01.03)

Pada percakapan 01.03 di atas terdapat implikatur yang mengungkapkan 'ketidaksetujuan'. Kalimat "Nah, bagaimana dengan siswa yang membutuhkan istirahat, apa ia tidak jenuh? Ketika ia baru selesai belajar, selanjutnya ia akan mengikuti kegiatan ekstrakulikuler, apakah tidak ada istirahatnya?" merupakan bentuk ketidaksetujuan terhadap pendapat yang disampaikan oleh penanya. Penyaji menggunakan kalimat introgatif untuk menyatakan ketidaksetujuannya.

\section{c. Implikatur pemberitahuan}

Implikatur

menyatakan

menyatakan pemberitahuan adalah apa yang diartikan, secara tersirat mempunyai maksud untuk memberitahukan sesuatu kepada mitra tutur. Contoh dari data yang menunjukkan implikatur yang 'menyatakan pemberitahuan' dapat dilihat pada percakapan di bawah ini.

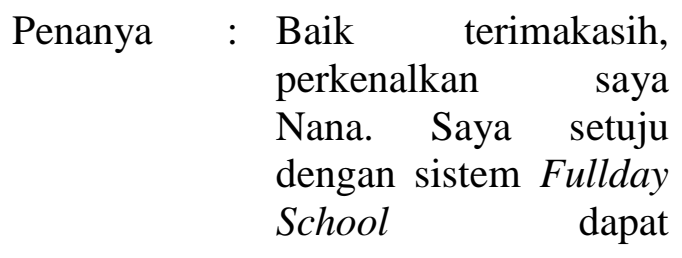

menghindarkan siswa dari pergaulan buruk....

Moderator : Baik, terimakasih atas tanggapan yang Anda berikan, kami akan menanggapi apa yang telah disampaikan oleh saudari Nana. (DS:01.03)

Pada tuturan "Baik, terimakasih atas tanggapan yang Anda berikan, kami akan menanggapi apa yang telah disampaikan oleh saudari Nana", ditujukan kepada peserta diskusi bahwa kelompok penyaji akan menanggapi pendapat yang telah disampaikan oleh Nana.

\section{d. Implikatur Menyuruh}

Implikatur menyuruh adalah apa yang diartikan, secara tersirat menyuruh mitra tutur untuk melakukan suatu hal. Contoh data yang menunjukkan implikatur menyuruh dapat dilihat pada percakapan berikut ini.

Penanggap : Menurut saya, ekskul dari masing-masing siswa itu berbeda, menurut hobi masingmasing. ....

Moderator : Oke, kami akan menunda dulu menanggapi pernyataan saudari Nana....(DS:01.06) 
Tuturan yang diungkapkan oleh moderator "Oke, kami akan menunda dulu menanggapi pernyataan saudari Nana" di atas termasuk ke dalam implikatur 'menyuruh' yang memiliki maksud bahwa peserta diskusi harus menunggu beberapa saat untuk penyaji menanggapi kembali pendapat sebelumnya.

Adapun wujud implikatur dalam tuturan acara kegiatan diskusi siswa SMA Negeri 1 Sumbawa Besar, secara lebih lengkap dapat dilihat pada tabel berikut:

Tabel 3

Wujud implikatur dalam kegiatan diskusi

\begin{tabular}{|l|l|l|}
\hline No & \multicolumn{1}{|c|}{ Prinsip } & \multicolumn{1}{c|}{ No. Data } \\
\hline 1. & $\begin{array}{l}\text { Implikatur } \\
\text { a. Menolak }\end{array}$ & - \\
\hline & b. Menyindir & 59 \\
\hline & c. Tidak setuju & $\begin{array}{l}13,16,22,26, \\
27,28,46\end{array}$ \\
\hline & d. Menyatakan & $01,04,09,12$ \\
& pemberitahuan & \\
\hline & e. Mengejek & - \\
\hline & f. Menyombongkan diri & - \\
\hline & g. Menyuruh & $06,10,11,14$, \\
& & $19,20,23,41$, \\
& & $48,52,54,55$, \\
& & 48 \\
\hline
\end{tabular}

Faktor-faktor Penyebab Terjadinya Penyimpangan Prinsip Kesantunan Berbahasa dalam Kegiatan Diskusi Siswa Kelas X SMA Negeri 1 Sumbawa Besar

Hasil analisis mengenai faktor-faktor yang menyebabkan terjadinya penyimpangan prinsip kesantunan berbahasa pada kegiatan diskusi siswa kelas X SMA Negeri 1 Sumbawa Besar ini diperoleh melalui teknik wawancara terstruktur sebagai bentuk pencarian data. Analisis ini terfokus pada siswa yang susah mengontrol emosinya dan susah memilih kata-kata yang tepat untuk berbahasa santun. Selain itu juga, peneliti melakukan wawancara kepada guru mata pelajaran guna memperoleh data pendukung mengenai factor penyebab terjadinya penyimpangan prinsip kesantunan berbahasa pada kegiatan diskusi.

Hasil wawancara dijelaskan dalam bentuk narasi. Penyebab penyimpangan prinsip kesantunan berbahasa bervariasi, namun mayoritas siswa melanggar prinsip kesantunan adalah karena mereka susah mengontrol emosi dan susah memilih kata yang tepat untuk berbahasa secara santun. Terdapat Sembilan responden yang menyatakan bahwa penyebab penyimpangan prinsip kesantunan adalah susahnya mengontrol emosi. Ketika kita sedang emosi, banyak siswa yang terkadang tidak dapat mengontrol perkataan, maka tidak menutup kemungkinan bahwa mereka menggunakan bahasa yang tidak santun. Apabila saya sedang emosi atau marah para siswa terkadang mengucapkan kata yang kurang baik atau tidak santun.

Adapun penyebab penyimpangan prinsip kesantunan karena kesulitan memilih 
kata atau bahasa yang tepat untuk berbicara santun, terdapat 19 responden. Kesulitan yang dialami siswa untuk berbahasa santun adalah susahnya memilih bahasa yang tepat, apalagi jika berbicara menggunakan bahasa yang baku.

Selain itu, siswa dituntut untuk berbicara santun hanya pada saat kegiatan belajar mengajar di kelas saja. Saat jam istirahat atau saat mereka bergaul dengan teman sebaya mereka, mereka menggunakan bahasa sehari-hari yang tidak santun. Jadi tidak menutup kemungkinan jika para siswa kesulitan memilih bahasa atau kata yang tepat untuk berbicara santun, karena tidak setiap saat mereka diwajibkan untuk berbicara santun.

Dari penjelasan jawaban para responden di atas, dapat diketahui bahwa mayoritas penyebab terjadinya penyimpangan prinsip kesantunan adalah karena faktor emosi, kesulitan memilih kata yang tepat untuk berbahasa secara santun, dan faktor lingkungan sekitar mereka.

Sementara itu, menurut guru bahasa Indonesia SMA Negeri 1 Sumbawa Besar, penyimpangan kesantunan yang sering dilakukan oleh siswa di antaranya adalah banyak siswa yang jarang menggunakan kata "maaf" dan "tolong", serta menggunakan kata-kata kasar. Hal itu dikarenakan guru hanya menuntut siswa untuk berbahasa santun pada saat proses pembelajaran di kelas. Inilah yang menyebabkan masih ada beberapa siswa yang masih belum lancer berbahasa santun, lupa, serta sering terpengaruh dengan bahasa daerah mereka.

\section{SIMPULAN}

Dalam penelitian ini dapat disimpulkan empat hal yang merupakan jawaban dari perumusan masalah yang telah dipaparkan sebelumnya. Simpulan dari penelitian ini dapat dilihat dari uraian berikut:

1. Dalam analisis yang dilakukan pada kegiatan diskusi siswa kelas X SMA Negeri 1 Sumbawa Besar, terdapat pematuhan prinsip kesantunan. Pematuhan tersebut meliputi empat dari enam maksim pada teori Leech. Maksim-maksim tersebut meliputi: maksim kebijaksanaan, maksim kedermawanan, maksim penghargaan, dan maksim kesimpatian.

2. Dalam analisis yang dilakukan pada kegiatan diskusi siswa kelas X SMA Negeri 1 Sumbawa Besar, terdapat penyimpangan prinsip kesantunan. Penyimpangan tersebut meliputi tiga dari enam maksim pada teori Leech. 
Maksim-maksim tersebut meliputi: maksim kebijaksanaan, maksim kedermawanan terdapat, dan maksim penghargaan.

3. Dalam analisis yang dilakukan pada kegiatan diskusi siswa kelas X SMA Negeri 1 Sumbawa Besar, terdapat lima implikatur percakapan. Implikatur tersebut adalah implikaturmenolak, implikatur menyindir, implikatur tidak setuju, implikatur menyatakan pemberitahuan, dan implikatur menyuruh.

4. Dalam analisis yang dilakukan pada kegiatan diskusi siswa kelas X SMA Negeri 1 Sumbawa Besar, terdapat fakor-faktor yang menyebabkan siswa melakukan penyimpangan prinsip kesantunan berbahasa. Faktor penyebab tersebut mayoritasnya adalah karena emosi dan susah memilih kata atau bahasa yang tepat untuk berbicara secara santun, sehingga membuat siswa kesulitan dan melakukan penyimpangan pada prinsip kesantunan berbahasa.

\section{DAFTAR PUSTAKA}

Ardianto, Wibi Kusuma. 2014. Prinsip Kesantunan dan Implikatur dalam Acara "Show Imah" di Trans TV: Suatu Tinjauan Pragmatik.
[Skripsi]. Surakarta: Universitas Sebelas Maret Surakarta.

Chaer, Abdul. 2010. Kesantunan Berbahasa. Jakarta: Rineka Cipta.

Chaer, Abdul dan Leonie Agustina. 2010. Sosiolingustik. Perkenalan Awal. Jakarta: Rineka Cipta.

Herdi, Rudika Novia. 2012. Realisasi Kesantunan Berbahasa di Facebook: Respon Masyarakat Terkait dengan Isu Kenaikan Harga BBM. [Skripsi thesis]. Surakarta: Universitas Muhammadiyah Surakarta.

Mawene, Aleda dan Eti Setiawati. 2011. Kesantunan Berbahasa dalam Sistem Pesan Singkat: Analisis Wacana Interaksi antara Mahasiswa dan Dosen Universitas Cendrawasih. Jurnal Artikulasi Vol. 12 No. 2

Miles, Matthew B. dan A. Michael Huberman. 2009. Analisis Data Kualitatif: Buku Sumber Tentang Metode-metode Baru. Jakarta: UI Press.

Mislikhah, St. 2014. Kesantunan Berbahasa. Ar-Raniry: International Jurnal of Islamic Studies Vol. 1, No. 2

Moleong, Lexy J. 2013. Metode Penelitian Kualitatif (Edisi Revisi). Bandung: PT. Remaja Rosdakarya.

Nadar, F.X. 2009. Pragmatik dan Penelitian Pragmatik. Yogyakarta: Graha Ilmu. 
Nurdaniah, Mia. 2014. Prinsip Kesantunan Berbahasa Menurut Leech pada Novel Pertemuan Dua Hati Karya NH. Dini dan Implikasinya terhadap Pembelajaran Bahasa Indonesia di SMA. [Skripsi]. Jakarta: Universitas Islam Negeri (UIN) Syarif Hidayatullah.

Nurjamily, Wa Ode. 2015. Kesantunan Berbahasa dalam Lingkungan Keluarga.

Jurnal Humanika No. 15, Vol. 3

Rahadini, Astiana Ajeng. 2014. Kesantunan Berbahasa dalam Interaksi Pembelajaran Bahasa Jawa di SMP Negeri 1 Banyumas. Jurnal LingTera Vol. 1 No. 2

Rahardi,

Kunjana. 2005. Pragmatik:Kesantunan Imperatif Bahasa Indonesia. Jakarta: Erlangga.

Rahayu, Puji. 2011. Implikatur Percakapan Dalam Pembelajaran Bahasa Indonesia Di Kelas V Sd Negeri Pondok 1 Kecamatan Nguter Kabupaten Sukoharjo. [Skripsi]. Surakarta: Universitas Sebelas Maret Surakarta.

Sari, Mariana Catur Nopita. 2012. Pematuhan dan Pelanggaran Prinsip Kesantunan serta Implikatur Percakapan dalam Talk Show "Apa Kabar Indonesia Malam” di TV One: Suatu Tinjauan Pragmatik. [Skripsi]. Surakarta: Universitas Sebelas Maret Surakarta.
Sulistyo, Edy Tri. 2013. Pragmatik: Suatu Kajian Awal. Surakarta:UNS Press.

Tohirin. 2013. Metode Penelitian Kualitatif dalam Pendidikan dan Bimbingan Konseling. Jakarta: PT. Grafindo Persada.

Wijana, I Dewa Putu. 2011. Analisis Wacana Pragmatik. Kajian Teori dan Analisis. Surakarta: Yuma Pustaka.

Yule, George. 2006. Pragmatik. Yogyakarta: Pustaka Pelajar.

Sugiyono. 2015. Metode Penelitian Kuantitatif, Kualitatif dan $R \& D$. Bandung: Alfabeta. 